Click www.researchjournal.co.in/online/subdetail.html to purchase.

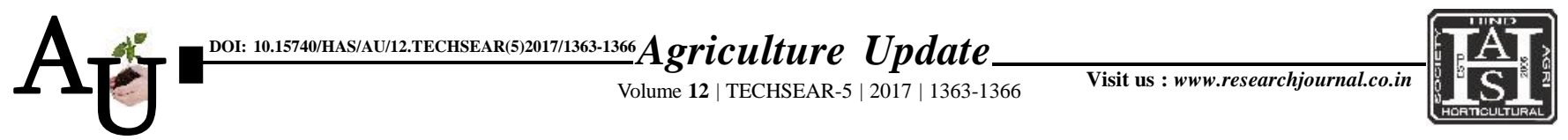

\title{
Rевевсн Автіске: Diversity of white grubs (Coleoptera: Scarabaeidae: Melolonthinae) from Maharashtra
}

\author{
口 VIJAYA V. BAJAD, S.M. DADMAL AND D.B. UNDIRWADE
}

Article Chronicle: Received :

15.07.2017;

Accepted :

30.07.2017

KEY Words:

Melolonthinae,

Diversity,

Distribution, White

grubs
SUMMARY : The present work provides information on distribution of white grub species from different seven agroclimatic zones of Maharashtra. A total of thirteen species from subfamily Melolonthinae under five genera viz., Holotrichia serrata (Fabricius), Holotrichia fissa Brenske, Holotrichia reynaudi (Blanchard), Holotrichia akolana Khan and Ghai, Holotrichia nagpurensis Khan and Ghai, Holotrichia rufoflava Brenske, Holotrichia ferinosa Nonfried, Sophrops karschi (Brenske),Sophrops sculpticollis (Blanchard), Schizonycha ruficollis (Fabricius), Schizonycha fuscescens (Blanchard), Leucopholis lepidophora (Blanchard) and Amiridiba cocaabiae recorded during the study period. The single dominant species, Holotrichia serrata was observed upto 29.20 per cent of all individuals followed by Holotrichia fissa, Schizonycha ruficolliswith abundance of 23.89 per cent and 19.17 per cent, respectively. The lowest abundance was observed in species Leucopholis lepidophora. Diversity index of subfamily Melolonthinae recordedabundance in population Holotrichia serrata (0.3594). Whereas, Leucopholis lepidophora with minimum abundance (0.0523). However, moderate to rich Shannon biodiversity index $(\mathrm{H}=1.9897)$ was noticed in terms of subfamily Melolonthinae in Maharashtra.

How to cite this article : Bajad, Vijaya V., Dadmal, S.M. and Undirwade, D.B. (2017). Diversity of white grubs (Coleoptera: Scarabaeidae: Melolonthinae) from Maharashtra. Agric. Update, 12(TECHSEAR-5) : 1363-1366; DOI: 10.15740/HAS/AU/12.TECHSEAR(5)2017/1363-1366.
Author for correspondence :

\section{VIJAYA V. BAJAD}

Department of Entomology, Dr. Panjabrao Deshmukh Krishi Vidyapeeth, AKOLA (M.S.) INDIA Email : vijayabajad2@ gmail.com

See end of the article for authors' affiliations 